\title{
Grounded Theory in Accounting Research
}

\author{
Zul Azmi ${ }^{1}$, Abdillah Arif Nasution ${ }^{2}$, Wardayani $^{3}$, Iskandar Muda ${ }^{4}$, Supriyanto $^{5}$, Syamsul Rizal $^{6}$, \\ Rahmat Hidayat $^{3}$ \\ \{zulazmi@umri.ac.id $\left.{ }^{1}\right\}$ \\ ${ }^{1}$ Department of Accounting, University Of Muhammadiyah Riau, Riau Indonesia \\ 2,Department of Accounting, University of Sumatera Utara,Sumatera Utara Indonesia \\ ${ }^{3,7}$ Department of Management, Sekolah Tinggi Ilmu Manajemen Sukma Medan, Sumatera, Utara \\ Indonesia \\ ${ }^{4}$ Department of Accounting, University of Sumatera Utara, Sumatera Utara Indonesia \\ ${ }^{5}$ Department of Bussines Administration, Politeknik LP3I Medan,Sumatera Utara, Indonesia \\ ${ }^{6}$ Department of Finance and Banking, Akademi Keuangan Perbankan Nusantara, Aceh, Indonesia \\ Telp. 061-7883991
}

\begin{abstract}
This article aims to discuss the use of grounded theory approach in qualitative research in accounting and management. Development of accounting theory one of them done with accounting research. Qualitative research can use grounded theory as a great tool that researchers can use to collect and analyze empirical data. Using the literature study, it was found that grounded theory has been used in accounting and management research such as budgeting, corporate governance, e-commerce, organizational control, information systems and behavior accounting. Grounded theory is particularly apt to unmask and understand what lies behindthe phenomenon of something relatively newly known.
\end{abstract}

Keywords: Grounded theory, accounting research and qualitative research

\section{Introduction}

Accounting theorists agree that no comprehensive theory of accounting has been developed, (Coetse, 2010). Therefore, the underlying principles of accounting to establish accounting standards need to be studied more comprehensively. Theory is generally developed and refined through the research process, (Wolk, H. I., 2004). However accounting principles are not only developed through accounting research. Involvement pf parties such as policy makers in organizations, public accounting firms, and private industries also play a role in the research process. In other words, accounting practices in organizations that go through the process of standard compilation also contribute to developing accounting principles.

Since accounting principles can be developed through accounting research, methodological choices in research are of major concern to the research objectives. Methodology is an important and vital part because it is a pattern used to produce science, while the form of science can be determined by the choice of methodology form appropriate to the discipline of science as the main foothold, (Triyowono, 1977). In some researchers, qualitative research is seen as second class research, Basri (Basri, 2014), (Bluhm, 2011). On the other hand, there is a belief that social science is seen as no different from exact sciences so that it can be studied in the same way as physical objects, (Kotler, 2010). Because quantitative research is used more to answer a problem, while qualitative research becomes less desirable. However, in recent literature some changes show that contemporary 
interdisciplinary research in accounting and management is increasingly using qualitative research methodology, (Alberti, A, L. Von and Al-Htaybat, 2010), (Chapman, 2008), (Triyowono, 1977), (Tillmann, K. and Goddard, 2008). Without prejudging the role of research with a vast quantitative method of research for accounting and accounting management in addition to qualitative approaches, this paper is intended to explain the role of qualitative research in accounting that is growing especially using the approach of gorunded theory. Qualitative research can provide many options for viewing, interpreting and interpreting a phenomenon that occurs in an environment such as using a grounded theory approach, (Basri, 2014). Grounded theory has been widely used in sociological research in three decades, (Kirk, 2001), and this approach began to develop in accounting research. This paper is prepared and attempted to explain; first, the introduction of grounded theory. Second, grounded theory can be applied to management and accounting research. Third, the challenges and limitations in grounded theory and concluding with conclusions and even contradiction of the research results one another. In addition, there are also differences in the research result with existing theories. This is what became a research gap in this research.

\section{The Literature Of Grounded Theory}

(Coetse, 2010) divides the two groups that occurred in the 1960s and early 1970s that significantly affected the development of current accounting theory. First, the group that leads from the normative method to the positive accounting methodology. This group became mainstream accounting research. Second, the group that leads to decision-usefulness orientation in accounting. Through decision-usefulness orientation, the focus of the study shifts from accounting principles to accounting process outcomes-where the information is available. Accounting is a human activity that should cover all approaches that include social science such as interpretive, critical research and research keprilakuan. In the decision usefulness approach, Grounded Theory can describe methods thoroughly and systematically collect and analyze data to create a theory. The theory of decision usefulness such as grounded theory has not been tested academically,(Inanga, 2005). This is in contrast to (Coetse, 2010) which sees the approach of desicison usefulness to the preparation of standards to form grounded theory. The grounded theory methodology can be used in accounting research to create accounting principles, concepts, and hypotheses in which mainstream accounting research uses.

Grounded theory was first developed by two sociologists namely Barney Glasser and Anselm Strauss in (Boadu and Sorour, 2015). They argue that researchers need methods that allow it to move from data to a theory, in order to emerge new theories. Grounded theory can be described as a method of research in which theories are developed from existing data, not reverse data developed from existing theories. There are two approaches developed after the introduction of grounded theory Glasserian and Strussian. Glasser and Strauss each have different views on the concept of grounded theory. Glasserian is more of an early grounded theory development, while Straussian is more conceptual. In this case Straussien emphasizes more detailed explanations of concepts such as sampling, coding and memo use. The differences between the two approaches focus on methodological procedures for data encoding, category development, emergency, researcher distance and theoretical development, (Boadu and Sorour, 2015)

Qualitative research using grounded theory method is not easy to implement by novice researchers, because it has a model of continuous data analysis, where data is still collected during the field. Researchers go directly to the field without bringing certain conceptual 
designs, propositions and theories. In other words, researchers plunge into the field with empty heads, without carrying anything of a priori nature, whether a concept, proposition or theory , (Kirk, 2001), (Boadu and Sorour, 2015), (Budiasih, 2014). This is because to avoid getting stuck on a verifikatif study tendency that imposes an empirical level adjusting to theoretical conceptual level. The researcher must remove the attitudes, views, alignments to a particular theory or science that is feared to be a great danger for theoretical preparation. However, grounded theory is particularly suited for unmasking and understanding what lies behind the phenomenon of something relatively newly known, (Strauss and Corbin, 1990).

\section{Stages Of Grounded Theory Method}

Qualitative research procedures using grounded theory consist of several stages performed simultaneously (Budiasih, 2014). The first stage is the formulation of the problem. The initial problem formulation is general in the form of questions with the freedom to explore the phenomenon broadly or specifically, but has not yet come to the affirmation of any variables within the scope of the problem. The initial problem formulation used guidelines for data collection activities. Once the data is collected, then the problem formulation can be narrowed and more focused on the nature of the data collected. The second stage is the use of theoretical studies. At this stage it should be understood that grouded theory is not intended to test the truth of a theory and not be influenced by the study of literature, nor does it depend on the various variables derived from a theory, because it can inhibit the development of new theory formulations.

Theories obtained from the results of research compared to the existing theory in the previous study. This comparison can improve the definition of constructs and increase validity. The third stage is data collection and sampling. At this stage, individual researchers are also used as a data-hammer instrument. Observations and interviews can be used as a method of data retrieval. Observations were made before and during the research. Interviews were conducted separately for each informant. Data can be obtained from various sources, which are not limited to observations and interviews. The phenomenon is then digged deeper by researchers at the time of data collection process. Stages of data collection and data analysis occur simultaneously. The fourth stage is data analysis. At this stage the coding form is performed which is the process of decompiling the data, drafting and rearranging in a new way. In the coding process can be divided into three levels namely open coding, axial coding, and selective coding, (Boadu and Sorour, 2015). Open coding aims to derive data into concepts by using theoretical procedures and constant comparison methods. Each entry data is then compared to identify similarities and differences. In the axial coding stage, begins the process of reassembling data that has been decomposed pda open coding stage. Then the relationship between categories and other related matters is identified to form a more complete and precise description of a phenomenon. After axial coding is followed by selective coding that integrates, interprets and refines the main categories and sub categories to construct an explanation of what challenges occur over the phenomenon. At the data analysis stage, the data were analyzed by comparing the methods and the analytic deductions.

The process of iterative comparisons, repetitive reading, memo writing, coding, forming categories and abstractions to produce something to be achieved continues to be done in grounded theory, (Kirk, 2001). Grounded theory has been used by management accounting researchers in a variety of research settings to obtain answers to the complexities of accounting practices (Tillmann, K. and Goddard, 2008), Elharidy (2008), Parker (2002). Grounded theory is used in the study of technological change (computerization) in health 
organizations, Prasad and Prasad (1994) research on organizational changes Brown and Eisenhardt (1997) that examines how an organization is in ever-changing events. In this situation, more grounded theory is expected to generate new views than if based on previous research. Some reviews of Grounded theory on accounting and management research can be presented in Table I. The literature on qualitative research using grouded theory in accounting and management has emerged in leading journals such as Management Accounting Research, Accounting, Organization and Society, Accounting, Auditing and Accountability Journal journals and other journals such as Qualitative Research in Accounting \& Management .

Table 1. Review of Grounded Theory implementation in accounting and management

\begin{tabular}{|c|c|c|c|}
\hline No & Name & $\begin{array}{l}\text { Research } \\
\text { Field }\end{array}$ & Tittle \\
\hline 1. & $\begin{array}{l}\text { Efferin } \\
\text { Hopper }\end{array}$ & $\begin{array}{l}\text { Management } \\
\text { control }\end{array}$ & $\begin{array}{l}\text { Management, culture and ethnic } \\
\text { controls on Chinese company } \\
\text { Indonesia (AOS) }\end{array}$ \\
\hline 2. & Brown & $\begin{array}{l}\text { Information } \\
\text { System }\end{array}$ & $\begin{array}{l}\text { Politics, symbolism, niche } \\
\text { marketing, and the search for } \\
\text { legitimacy on the } \\
\text { implementation of information } \\
\text { technology (Organization } \\
\text { studies) }\end{array}$ \\
\hline 3. & $\begin{array}{l}\text { Tilmann dan } \\
\text { Goddard [10] }\end{array}$ & $\begin{array}{l}\text { Management } \\
\text { Accounting }\end{array}$ & $\begin{array}{lr}\text { Management } & \text { accounting } \\
\text { strategy and } & \text { sense-making in } \\
\text { multinational } & \text { companies } \\
\text { (Management } & \text { Accounting } \\
\text { research) } & \\
\end{array}$ \\
\hline 4. & $\begin{array}{lr}\text { Fathul Himam, } \\
\text { Bagus Riyonon } \\
\text { dan Sumaryono } \\
{[21]}\end{array}$ & $\begin{array}{l}\text { Strategy } \\
\text { Management }\end{array}$ & $\begin{array}{l}\text { Grounded Theory Approach to } \\
\text { understanding DIY regional } \\
\text { government strategy in facing } \\
\text { the era of regional autonomy } \\
\text { and globalization }\end{array}$ \\
\hline 5. & $\begin{array}{ll}\text { Boadu } & \text { dan } \\
\text { Sorour [13] } & \end{array}$ & $\begin{array}{l}\text { Corporate } \\
\text { Governance }\end{array}$ & $\begin{array}{l}\text { Utilization of Grounded Theory } \\
\text { in business research } \\
\text { (international Journal of } \\
\text { doctoral Research) }\end{array}$ \\
\hline
\end{tabular}

\section{Challenges And Limitations Of Grounded Theory}

Although grounded theory has an advantage and is a good methodology development methodology that can be used in business research, but there are several challenges faced by researchers, Chreswell (1998), (Widjajani et al., 2009) first, the researcher must put aside any theoretical or conceptual notions before the new analytical substantive theory can be brought up. Second, researchers should be aware that this research is systematic with specific steps in data analysis. Third, researchers have difficulty determining when a category has reached maturity or when the theory has been sufficiently detailed. Fourth, the main output of this research is the theory with the specific elements of the main phenomena, causal conditions, 
strategies, conditions and context, and consequences. This is a category that should be explained in a theory.

Understanding and knowing the limitations of grounded theory can be useful for developing the next research. Grounded theory is criticized for several reasons , (Boadu and Sorour, 2015), (Kirk, 2001): First, focusing extensively on intermediate theory, rather than actually generating more general theories. Second, it can lose context and narrative current during the coding process. Third, too much emphasis on the explanation of respondents based on experience that can hinder the clarity of understanding. Fourth, based on the theoretical sensitivity of the researcher, so much needed intellectual, emotional and commitment discipline.

\section{Conclusions}

a. Grounded theory is particularly suited for unmasking and understanding what lies behind the phenomenon of something relatively newly known (Strauss and Corbin, 1990). This situation applies when researchers are needed to open and begin searching for what really happened, where there is no theory to explain certain conditions, (Kirk, 2001). In other words, the grounded theory approach is useful for addressing new issues in changing situations. Given its limits, it requires deep understanding of the methodology, stages of planning and conducting research. In addition, intellectual ability support, emotional control, individual commitment, honesty and time availability are essential

b. Accounting research and interpretive management require data availability and be open to complexity contexts. One solution to the problem is to use grounded theory. Grounded theory can be a powerful tool that researchers can use to collect and analyze empirical data

\section{References}

[1] Alberti, A, L. Von and Al-Htaybat, K. (2010) “"Qualitative accounting research: an account of Glaser"s grounded theory', Qualitative Research in Accounting \& Management. 10.1108/11766091011050868.', in, pp. 208-226. doi: $10.1108 / 11766091011050868$.

[2] Basri, H. (2014) “"Using Qualitative Research in Accounting and Management Studies: Not a New Agenda", Basri, H., 11(10), pp. 831-838. doi: 10.17265/15486591/2014.10.003.

[3] Bluhm, D. J. et al (2011) "'Qualitative Research in Management: A Decade of Progress"., Journal of management Studies, 48(8), pp. 1866-1891.

[4] Boadu and Sorour (2015) "'On Utilizing Grounded Theory in Business Doctoral Research: Guidance on the Research Design, Procedures, and Challenges".', International Journal of Doctoral Studies, 10, pp. 143-166.

[5] Budiasih (2014) “'Metode Grounded Theory dalam Riset Kualitatif”, 9(1), pp. 19-27.', Jurnal Ilmiah Akutansi dan Bisnis, 9(1), p. 19-27.

[6] Chapman, C. S. (2008) "We are not alone: qualitative management accounting research: Rationale, pitfalls and potential", Qualitative Research in Accounting \& Management.', 5(3), p. 247-252.

[7] Coetse, D. (2010) "'The role of accounting theory in the development of accounting principles", Meditari Accountancy Research', 18(1), pp. 1-16.

[8] Inanga, and S. (2005) "The failure of accounting research to improve accounting practice: a problem of theory and lack of communication", Critical Perspectives on 
Accounting, $\quad 16(3), \quad$ p. 227-248. doi: doi: https://doi.org/10.1016/S10452354(03)00073-X.

[9] Kirk, N. et. al. (2001) “"The use of grounded theory in accounting research”,' Meditari Accountancy Research, 9(1), pp. 175-197.

[10] Kotler, P. (2010) Principles of Marketing. Pearson Education.

[11] Strauss and Corbin (1990) Basics of qualitative research: grounded theory procedures and techniques. Newbury Park, California: Sage Publications.

[12] Tillmann, K. and Goddard, A. (2008) "'Strategic management accounting and sensemaking in a multinational company", Management Accounting Research,' 19(1), pp. 80-102. doi: 10.1016/j.mar.

[13] Triyowono, I. (1977) 'Metodologi islamisasi ilmupengetahuan (orientasi masa depan) dalam salam,', Jurnal Pasca Sarjana Universitas Muhammadiyah Malang $2 \& 3$.

[14] Widjajani et al. (2009) “"Penggunaan Soft System Methodology Dan Grounded Theory Dalam Membangun Teori Pada Penelitian Proses Strategi (Strategy Process Research)"', Jurnal Manajemen Teknologi, 8(1).

[15] Wolk, H. I., et. al. (2004) Accounting theory: conceptual issues in a political and economic environment. Edited by 6th edn. South-Western: Norwalk,: onn.: Thomson. 